\title{
The long indigenous history in the eastern amazon (Pará-Brazil)
}

\begin{abstract}
In the archeology of the Amazon there are arguments that, by the force of repetition, end up being considered true, although this is not the intention. Such is the case with the classificatory assumptions that underlie the traditional historical narrative about the regional human presence. There were decades when this classificatory history began only from the evidence of the presence of horticultural populations leaving, until the $1986 \mathrm{~s}$, the existence of hunter-gatherers in doubt. The consequence was the absence of most of the history that humans developed in the Amazon. And this absence had a devastating effect on the way endogenous cultures, processes and populations were understood and classified.
\end{abstract}

Keywords: amazon, lower holocene, historical processes, archeology, pleistocene/ holocene, carajás
Volume 4 Issue 5 - 2019

\section{Marcos Pereira Magalhães}

Researcher, Department of Humanities, Museu Paraense Emílio Goeldi, Brazil

Correspondence: Marcos Pereira Magalhães, Researcher, Department of Humanities, Museu Paraense Emílio Goeldi, Brazil,Tel 55 91981246898,Email mpm@museu-goeldi.br

Received: October 16, 2019 | Published: October 31, 2019

\section{Introduction}

Archeology of the Amazon does not have a very adequate principle of thought when it comes to the complex historical evolution of human societies that lived in it from the Pleistocene/Holocene passage to the Middle Holocene. On the other hand, quite simply, the best considered historical periods or phases, which emerge from the Middle Holocene, are focused on societies organized according to the chronological and typological classification of material culture, in particular that represented by ceramics. Favored by research begun more systematically since the 1950 s, by the easy access and visibility afforded by the navigability of the great rivers, these societies were privileged, but those that preceded them were left in the background. Since then, the historical culturalist mainstay that underlies the chronology of the regional human occupation is the technological or stylistic changes passed by the material artifacts, according to supposed original and hierarchical points of cultural diffusion. Although in discourse there is a concern to go beyond culturalist conjectures, such as through linguistics and the origins of the domestication of some plants, in practice what we have is the permanence of the ceramic dictatorship telling where certain cultural traditions came from and where they went. Consequently, the historical processes societies have undergone over time are ignored or deeply alleviated. Especially of those populations that emerged and lived in the Amazon between the early and middle Holocene. Thus, shrouded by glorious and supposed but fleeting inner-state states, the genuinely Amazonian possible civilizations, their long territorial evolution and complex historical transformations, remain buried in the dust of indifference.

However, this is not an absolute truth. There are few but sincere attempts to make readings to narrate the historical evolution of man in the Amazon since his arrival in the region. Clearly complex fact given the small volume of research in a region of continental proportions. This volume of research is even smaller when we refer to the beginning of regional human colonization, which occurred between the late Pleistocene and the beginning of the Holocene. To get an idea, of the 2209 archaeological sites identified (until 2018) and or studied by archaeologists at the Paraense Emilio Goeldi Museum, 32 or less than $2 \%$ were those known as hunter-gatherers. And of the 32 known, only 25 were fully or partially studied. And of these, 23 are in Carajás (southeastern Pará-Eastern Amazon), which is, therefore, the area with the most significant results. This picture does not change much when we include the sites studied by other Amazonian institutions and researchers, who only circumstantially carry out research with this type of site, usually because of random discoveries rather than specific projects. To cite an example, in a recent publication focusing on the occurrence of sites in the focus period, but including areas outside the legal Amazon under the influence of the Tocantins river basin (upper, middle and lower course), Bueno et al (2019) accounted for 4825 of these are from Carajás. But if we are to compute only the sites located in the legal Amazon and dating from 12,000 to 9,000 years, except those of Carajás, the amount of them, besides not reaching a dozen, is scattered throughout the region. That is, the eastern Amazon, thanks to Carajas, is the archaeological territory of the Amazon that presents the largest volume of studies and, consequently, the one that allows theoretical speculations that could be tested.

For this reason, since the 1990s and more intensely, between 2011 and 2018, we propose, refine and test the idea that it was the first successful human waves in the regional colonization that inaugurated a long-term historical process, with emergence and autochthonous cultural collapse, whose greatest contribution was the Amazonian anthropogenesis. The idea developed came to the concept of Tropical Culture as a long-lasting historical process, which began around 12000 years ago, peaking around 9000 years ago, ending in the midHolocene with the rise of a new historical process. derived from it, the Anthropical Culture. ${ }^{1}$ The populations that engendered this process were based on tropical forest resources such as hunting (small), fishing, and plant gathering. The latter formed a group of culturally selected plants (for food, crafts, construction, medicine, etc.), which was gradually expanded and intensified. ${ }^{2}$ Consequently, unlike other concepts that attributed to them dependence on the availability of natural resources or the advent of agricultural societies, so that through exchange they could live in the rainforest, they were already able to make, through the management and manipulation of plants. , naturally poor environments in culturally rich environments. That is, it is likely that over time one human group or another would grow plants well before the advent of systematic agriculture. Before proceeding, it should be emphasized that the concept of Tropical Culture, because it involves a long-term, but temporally defined historical process, underpins the idea of deep history. According to how the concept of deep history was defined, ${ }^{3,4}$ it would not be possible to address the human occupation of the Amazon over time, as it does not define periods or changes in the historical trajectory of man in the region. 
Moreover, because it comes from a concept elaborated in geology, whose temporality is immensely greater than that of archeology, it can lead us beyond the Holocene, to pleistocene populations whose traces are found in the regional periphery of the Amazon, which reach more than 30.000 thousand years ${ }^{5}$ in São Raimundo Nonato (PI) and more than 20.000 years $^{6}$ in Santa Elina (MT), for example. These pleistocene populations, in turn, would not represent the ancestral populations of the Amerindians, but rather the heirs of the populations that initiated the successful colonization of the Amazon on the Pleistocene/Holocene passage, and whose genetic studies point to their arrival in the Americas as the same. about 18,000 years ago. ${ }^{7}$

That is, as a consequence of the cultural and social evolution of the populations of Tropical Culture, it is understood that the sedentary agricultural populations of the Amazon rainforest would be their descendants, constituting, however, another historical process, that of the Anthropical Culture. ${ }^{1,8}$ The populations of the Anthropical Culture would have exponentially expanded the use and consumption of vegetables, through the systematic cultivation of domesticated plants, which not by chance, were the same known and used by the populations of Tropical Culture, the pioneers in their consumption and manipulation. Thus, the difference between these two historical periods is fundamentally based on the mode of production. ${ }^{2}$ As Santos et al. ${ }^{9-11}$ and Lima et al. ${ }^{12}$ have shown, in Carajás several evidences of plant use and management have been found since 11.600 years ago. Initially, plant products were mostly derived from palm trees. Over time, plant diversity has grown. However, around 9000 ago, all the regional plants that were later consumed by sedentary and farming populations were already known and used by the populations of the Tropical Culture, including, among others, cassava (Manihot $\mathrm{sp}$ ). ${ }^{12}$ In addition, Santos et al. ${ }^{11}$ through a botanical inventory around archaeological sites, found that the vegetation of these environments would be of anthropic origin, indicating that they were culturally built landscapes, which had large trees, such as Bertholletia excelsa (chestnut) and Caryocar villosum (pequiá), and palm concentrations such as açaí (Euterpe oleracea) and bacaba (Oenocarpus bacaba).

The landscapes built by the populations of the Tropical Culture would be the historically conquered result of human knowledge knowing how to interfere and be interfered by the available natural resources. Instead of being dominated by nature or being its controller, the people of Tropical Culture were those who, from understanding the environments in which they lived, multiplied natural diversity in their own favor, benefiting the geographical distribution of that same diversity. However, as we are talking about Man as a historical being, all this integrative experience was only possible through a long process that began, was effective and ended. But this process has nothing to do with the linear periodization of historical culturalism, which, once applied by Anna Roosevelt ${ }^{13}$ in the Amazon, distributed the cultural evolution of societies according to hierarchically defined periods, such as Paleoindian, Archaic, Formative and Cacicado. In a different and asymmetrical way, the end of Tropical Culture was the beginning of another historical process derived from it, but one that will develop a much higher level of social complexity, implying the emergence of domesticated plants cultivation and the greater sedentary lifestyle of their populations. This new historical process, the Anthropical Culture, expands and intensifies the use and management of plants, resulting in large managed forests, large discharges of organic matter into the soil (resulting in the well-known TPAs-black Indian soil) and sophistication and social expansion of the oil industry. Like management and cultivation, this technology would most likely have been developed by Tropical Culture populations. This argument is supported by ancient pottery dating, which dates back over 5.000 years and is at least contemporary with the transition from Tropical Culture/Anthropical Culture in some mid-Holocene millennium.

\section{Conclusion}

Anthropical Culture, unlike Tropical Culture, has a very broad level of study, because its traces are concentrated in the so-called ceramist and/or black earth sites. Therefore, it implies a historical time span well known in the archaeological studies of the Amazon. However, due to the absence of a narrative that considers only the contextual dynamics of the history of the peoples who inhabited the Amazon before the European conquest, the diachronic trajectory of the societies of anthropical culture has been lined up in the broader process of western history, where they are only as pre-colonial occupations. But, as Bueno ${ }^{14,15}$ noted, the history of the ancient American peoples must be understood as a narrative about their own origins. Therefore, as this story has a founding milestone, it also has a closing milestone. In the case of Anthropical Culture, its closure will coincide with the implementation of the Portuguese colonial project, whose success will result in the end of indigenous Amazonian cultures and the rise of another historical process, whose landmarks have exogenous roots, without any contextual link with historical processes Amazon.

\section{Acknowledgments}

None.

\section{Conflicts of interest}

Author declares that there is no conflict of interest.

\section{Funding}

None.

\section{References}

1. Magalhães MP, Lima PGC, Santos R, et al. The Lower Holocene and Amazonian anthropogenesis during the long indigenous history of the Eastern Amazon (Carajás, Pará, Brazil). Bol Mus Para Emílio Goeldi Ciênc. 2019;14(2):291-325.

2. Magalhães MP. A arqueologia da Amazônia pela perspectiva interrelativa. In: Magalhães MP, editor. Amazônia antropogênica. Belém: Museu Paraense Emílio Goeldi; 2016. p. 95-118.

3. Mcgrath A. Deep histories in time, or crossing the great divide? In: Mcgrath Ann, JEBB Mary Anne, editors. Long history, deep time: deepening histories of place. Australia: ANU Press; 2015. p. 1-31.

4. Smail DL, Shryock A. History and the 'pre'. The American Historical Review. 2013;118(3):709-757.

5. Lourdeau A. A The Serra da Capivara area and the first settlements in South America: a bibliographical review. Bol Mus Para Emílio Goeldi Ciênc hum Belém. 2019;14(2):367-398.

6. Vilhena Vialou A, Vialou D. Symbolic expressions in the Santa Elina shelter, Mato Grosso, Brazil: rock art images, artifacts, and adornments from the Pleistocene to the late Holocene. Bol Mus Para Emílio Goeldi Ciênc hum. 2019;14(2):343-365.

7. Da-Gloria Pedro. The initial settlement of the Americas from a bioarchaeological perspective. Bol Mus Para Emílio Goeldi Ciênc hum Belém. 2019;14(2):429-457. 
8. Magalhães MP. Assim caminhou a humanidade... em Carajás. In Magalhães MP, editor. A humanidade e a Amazônia: 11 mil anos de evolução histórica em Carajás. Belém: Museu Paraense Emílio Goeldi; 2018. p. 233-258.

9. Santos RS, Lima PGC, Coelho-Ferreira M, et al. Estudos botânicos realizados em Carajás e as perspectivas para uma abordagem etnobiológica e paleobotônica. Amazônia antropogênica. Belém: Museu Paraense Emílio Goeldi; 2016. p. 199-214.

10. Santos RS, Lima PGC, Coelho-Ferreira M, et al. Useful plants and their relation to archaeological sites in the serra de Carajás, Brasil. An Acad Bras Ciênc. 2019;91(1):e20170909.

11. Santos RS, Lima PGC, Silva KCL, et al. Serra de Carajás Useful Plants: species associated with archaeological sites. Belém: Museu Paraense Emílio Goeldi. 2019
12. Lima PGC, Santos RS, Magalhães MP, et al. Plantas úteis na flora contemporânea e pretérita de Carajás. A humanidade e a Amazônia: 11 mil anos de evolução histórica em Carajás. Belém: Museu Paraense Emílio Goeldi; 2018. p. 183-209.

13. Roosevelt AC. Amazonian archeology. In: Cunha MC, editor. History of the Indians in Brazil. São Paulo: Cia. Das Letras; 1992. p. 53-86.

14. Bueno L. The Archaeology of early peopling of America or Ancient History of America: how old could be a 'New World'? Boletim do Museu Paraense Emílio Goeldi. Ciências Humanas. 2019;14(2):477-495.

15. Bueno L, Batarello J, Lima F. The Tocantins River Valley Between the Pleistocene and the Middle Holocene: Discussing Hypotheses on Population and Borders. La Plata Museum Review. 2019;4(2):437-462. 